\title{
The importance of hospital dentistry: oral health status in hospitalized patients
}

Importância da Odontologia hospitalar: condição de saúde bucal de pacientes internados

Cristhiane Olívia Ferreira do AMARAL'

(iD) ORCID iD 0000-0002-6153-6031

Letícia Marçal Ruthes BELON ${ }^{1}$

(iD) ORCID iD 0000-0002-2404-1689

Elza Aparecida da SILVA'

(iD) ORCID iD 0000-0002-2347-428X

Andressa de NADAI ${ }^{1}$

(iD) ORCID iD 0000-0001-9925-2491

Marcelo Sávio Paiva do AMARAL FILHO²

(iD) ORCID iD 0000-0002-1061-620X

Fabiana Gouveia STRAIOTO ${ }^{1}$

(D) ORCID ID 0000-0001-6756-0836

\section{ABSTRACT}

\section{Objective}

This research study aimed to evaluate the oral health status and the need for dental treatment in hospitalized patients, analyzing the importance of dentistry in hospitals. Therefore, the goal of this research study was to evaluate the oral health status, the need for dental intervention and the patient's opinion about the importance of having dental surgeons in hospital settings.

\section{Methods}

103 hospitalized patients were evaluated considering the DMFT index, gingival condition, visible biofilm index, and the need for invasive dental treatment. Volunteers were also asked about their opinion considering the importance of dentistry in hospital settings.

\section{Results}

$68.9 \%$ of volunteers were male subjects and $31.1 \%$ female subjects. The mean DMFT was 17.9 and $96.1 \%$ of subjects had their oral hygiene kit with when came to hospital, $97.1 \%$ of subjects stated that the presence of dental surgeons is necessary in the hospital setting and 63.1\% of subjects presented poor biofilm removal. The need for invasive dental treatment was as follows: restorations (68.9\%), extractions (40.8\%), endodontics (23.3\%), dental pain (26.2\%) and presence of abscess $(7,8 \%)$.

\section{Conclusion}

Oral health and hygiene status of patients were classified as poor and most of patients showed the need for invasive dental treatment. The majority of patients reported that dental care is very important in hospitals settings.

Indexing terms: Hospital dental team. Dental care. Oral Health.

\section{RESUMO}

Objetivo

Avaliar a condição de qualidade de saúde bucal e as necessidades de intervenção odontológica em pacientes hospitalizados, analisando a importância da presença da Odontologia em ambiente hospitalar.

\section{Métodos}

Foram avaliados 103 pacientes hospitalizados, por meio do índice CPO-D, condição gengival, índice de biofilme visível e índice de necessidade de tratamento invasivo odontológico. Observando a importância que estes pacientes davam a Odontologia hospitalar.

\section{Resultados}

Dentre os voluntários avaliados, 68,9\% do gênero masculino e 31,1\% feminino. A média do CPO-D foi de 17,9. Dentre os pacientes examinados: $96,1 \%$ levaram kit de higiene bucal, 97,1\% achavam importante a presença do cirurgião-dentista no hospital, 63,1\% apresentaram remoção de biofilme deficiente. Os pacientes apresentaram necessidade de tratamento odontológico invasivo: restauração (68,9\%), exodontia (40,8\%), endodontia $(23,3 \%)$, dor de origem odontológica $(26,2 \%)$, presença de abcesso $(7,8 \%)$.

\section{Conclusão}

A qualidade de saúde e de higiene bucal dos pacientes foi considerada insuficiente. A maioria dos pacientes necessitavam de algum tipo de tratamento odontológico invasivo, podendo levar a complicações na saúde bucal no momento da internação. A grande maioria dos pacientes acharam importante a assistência odontológica em hospitais.

Termos de indexação: Equipe hospitalar de Odontologia. Assistência odontológica. Saúde bucal.

${ }^{1}$ Universidade do Oeste Paulista, Faculdade de Odontologia. Rua José Bongiovani, Cidade Universitária, 19050-920, Presidente Prudente, SP, Brasil. Correspondência para / Correspondence to: COF AMARAL. E-mail: <crisamaral@unoeste.br>.

${ }^{2}$ Universidade do Oeste Paulista, Faculdade de Medicina. Presidente Prudente, SP, Brasil.

\section{$\mathbf{\nabla} \mathbf{\nabla}$}

Como citar este artigo / How to cite this article

Amaral COF, Belon LMR, Silva EA, Nadai A, Amaral Filho MSP, Straioto FG. The importance of hospital dentistry: oral health status in hospitalized patients. RGO, Rev Gaúch Odontol. 2018;66(1):35-41. http://dx.doi.org/10.1590/1981-863720180001000053410 


\section{INTRODUCTION}

Multiprofessional interaction should be a continuous action among health care teams in hospitals, comprising physicians, nurses, nursing technicians, nutritionists, physiotherapists, dentists and other areas with the single purpose of offering integral treatment to patients ${ }^{1-3}$. Dental surgeons should be the team member responsible for the implementation of oral care educational and preventive actions in the hospital setting.

Oral hygiene of hospitalized patients is poor due to the patient's disability, motivation of companions, lack of oral hygiene material and devaluation of the multiprofessional team ${ }^{4,5}$.

Dental surgeons should be a permanent member of the hospital staff, presenting skills and abilities to perform the dental care of hospitalized patients, aiming at eliminating possible infectious focus, installation of opportunistic infections and painful symptomatologies, which contributes to the extension of the hospitalization period $^{6,7}$.

A subject cannot be considered healthy presenting compromised oral health ${ }^{8,9}$. Unsatisfactory oral hygiene is frequently seen in hospitalized patients ${ }^{10}$, favoring bacterial colonization and developing oral biofilms composed of microorganisms found in the oral cavity and colonizers of the respiratory tract. The omission of biofilm control in hospitalized patients is related to the presence and development of severe gingivitis, periodontitis and additional buccal complications ${ }^{11-17}$.

The implementation of preventive protocols, aiming at maintaining the oral health, is fundamental in reducing general health problems. Biofilm control using chemical (antiseptics) and mechanics methods play an important role in order to reduce the microbial load, decrease the risk of microorganism aspiration and the installation of pneumonia in critically ill patients ${ }^{18}$.

In hospital settings, preventive dental management should comprise actions as mechanical removal of biofilms and lingual sores, prosthetics hygiene and atraumatic restorations. Oftentimes, because the disease is installed, it is necessary to adopt healing actions in hospital dentistry, which includes the accomplishment of exodontics, surgery, diagnosis and treatment of oral lesions ${ }^{14}$.

Oral health status without infectious focus and dental pain, and the establishment of a routine in oral hygiene habits of hospitalized patients considerably reduces the period of hospitalization. Strengthening the importance of the dental surgeon in the clinical staff of hospitals, as a member of the multiprofessional team, responsible for the motivation, oral health education and training of hospitalized patients is a need ${ }^{15,23}$.

This study is justified by the importance of maintaining the oral health of hospitalized patients because the presence of problems and oral diseases can damage the general health condition of patients. Hospital Dentistry plays an important role in the integral treatment of patients. Dental surgeons should be part of the hospital's multidisciplinary team, assisting in the improvement of the patient's integral health.

The goal of this research study was to evaluate the oral health status of hospitalized patients, as well as the need for dental intervention, and their opinion considering the importance of a dental surgeon in a hospital setting.

\section{METHODS}

This is a clinical, observational, cross-sectional, uncontrolled research study carried out in hospitalized patients, evaluating conditions that, during hospital stay, may aggravate the oral health status of patients, compromising their general health.

This research study was submitted to the 'Research Ethics Committee' of UNOESTE and was approved under protocol number 617.699. Patients who participated in this research were informed about the purpose of the study, as well as the methods applied, and signing the 'Informed Consent Term'.

\section{Research location and study population}

The evaluation was carried out in the wards of the hospitalization sector of the Regional Hospital of Presidente Prudente, a public hospital in the region attending almost fifty cities, in which the following hospital wards were addressed: surgical, orthopedics and traumatology, medical clinic, infectious diseases and cardiology wards.

In this research study, the criteria for participation were the following ones: total edentulous subjects with over 18 years of age, with hospitalization period greater than five days, being conscious and not dependent on oral hygiene, not during feeding hours, only at meal intervals. There was no exclusion as to gender or race. Individuals who needed hospitalization caused by trauma or orofacial diseases, psychiatric patients or patients with neurological diseases with cognitive impossibility of cooperation were excluded from the sample. Furthermore, immunodepressed 
subjects and subjects presenting coagulation disorders were also excluded from the sample.

\section{Procedures for data collection}

This research study comprised 103 patients approached by the researchers in the ward's bedside. An anamnesis was carried out, including age, gender, place of origin, general health status, oral health status, dental history, oral hygiene habits, oral hygiene kit presence. The importance the patient gives to dental surgeons working in hospitals was also considered.

Data collection considering the period and the reason for hospitalization, systemic diseases and medication used were taken from the hospital's records. After the interview and annotation of the medical records, the bucco-dental clinical evaluation was carried out.

The dental examination was performed by one examiner, so as not to have differences in diagnosis. The researchers used personal protective equipment (PPE) and the examination was carried out in the patient's bedside, with the aid of a manual flashlight, for better evaluation, and a clinical autoclaved instrument (mirror, forceps and exploratory probe). In the clinical evaluation, the following points were determined in all the volunteers: caries experience by the DMFT index, gingival health, biofilm checking, and need for invasive dental treatment (INI).

The DMFT index was applied to verify the past and current history of dental caries disease in patients. Data were recorded according to the criteria for the diagnosis of dental condition proposed by the World Health Organization.

The presence or absence of dental biofilm was determined by the visible biofilm index, consisting of evaluating the dental biofilm of all dental faces, verifying and checking the patient's ability to control dental biofilm.

The evaluation of the presence of dental biofilm was performed using the visible biofilm index presented by Ribeiro ${ }^{24}$, being evaluated as follows: Score 0: absence of visible biofilm; Score 1: presence of fine biofilm only on the anterior teeth; Score 2: presence of fine biofilm distributed on the anterior and the posterior teeth; Score 3: presence of thick biofilm only on the anterior or the posterior teeth; Score 4: presence of thick biofilm on the anterior teeth and thin biofilms on the posterior teeth or vice versa; and Score 5: presence of thick biofilm on the posterior and the anterior teeth. Score 0: excellent hygiene, score 3 and 4 regular hygiene and score 4 and 5: poor hygiene.

The gingival health status was evaluated observing the presence of gingivitis and the deficiency in biofilm control. Scores for gingival condition were established according to Ribeiro 25 : The checking was performed through the following scores: Score 0: visibly healthy gingiva. After using the probe, the gingiva did not show induced of spontaneous bleeding; Score 1: After using the probe, the gingiva bled; Score 2: With the use of gauze pad to dry the gum, there is spontaneous bleeding without the use of a clinical probe.

Considering the modified index need for invasive dental treatment (INI) proposed by Lobão et al. ${ }^{18}$ the following types of invasive dental procedures were verified: Score 0: Oral cavity with no need for invasive treatment; Score1: Need for restorative treatment-dental cavity: acute caries lesion, absence of restoration, fractured restoration; Score 2: Need for endodontic treatment: clinical visual analysis considering the need for endodontic treatment; Score 3: Need for exodontics; Score 4: Need for periapical or periodontal abscess drainage; Score 5: Dental pain.

\section{Statistical methodology}

The results were evaluated applying the Fisher's Exact test and the Chi-Square test. 5\% significance level was considered in the study. The analyzes were performed with SAS * (SAS Institute Inc., Cary, NC, USA, Release 9.2, 2010).

\section{RESULTS}

This research study aimed at verifying the possible causative factors that could interfere in the oral health condition of hospitalized patients. Table 1 shows that the mean age of subjects was 53.1 years of age, with a minimum age of 18-year old subjects and a maximum of 83-year old subjects. The average DMFT is 17.9 , with a minimum of 2 and a maximum of 32 .

Table 2 shows that, from the total sample, $31.1 \%$ were female subjects and $68.9 \%$ were male subjects. Among these subjects, $96.1 \%$ brought the oral hygiene kit to the hospital, $92.2 \%$ could do the cleaning alone, $28.2 \%$ felt pain in the oral cavity, $34.0 \%$ were happy with their oral health status and $97.1 \%$ found it very important the presence of dental surgeons in the hospital setting.

Table 3 shows that $63.1 \%$ of subjects presented poor oral hygiene, $44.7 \%$ of subjects presented gingival bleeding after conducting the probing procedure (induced bleeding) and $17.5 \%$ of subjects presented gingival bleeding with spontaneous bleeding. 
Table 1. Descriptive analysis of variables, Age, DMFT.

\begin{tabular}{|c|c|c|c|c|c|}
\hline Age & 53.14 & 16.04 & 54.00 & 18.00 & 83.00 \\
\hline D & 1.95 & 2.68 & 1.00 & 0.00 & 13.00 \\
\hline$M$ & 12.22 & 8.46 & 11.00 & 0.00 & 30.00 \\
\hline $\mathrm{F}$ & 3.70 & 3.49 & 3.00 & 0.00 & 13.00 \\
\hline
\end{tabular}

Table 2. Distribution of frequencies according to the studied variables in hospitalized subjects.

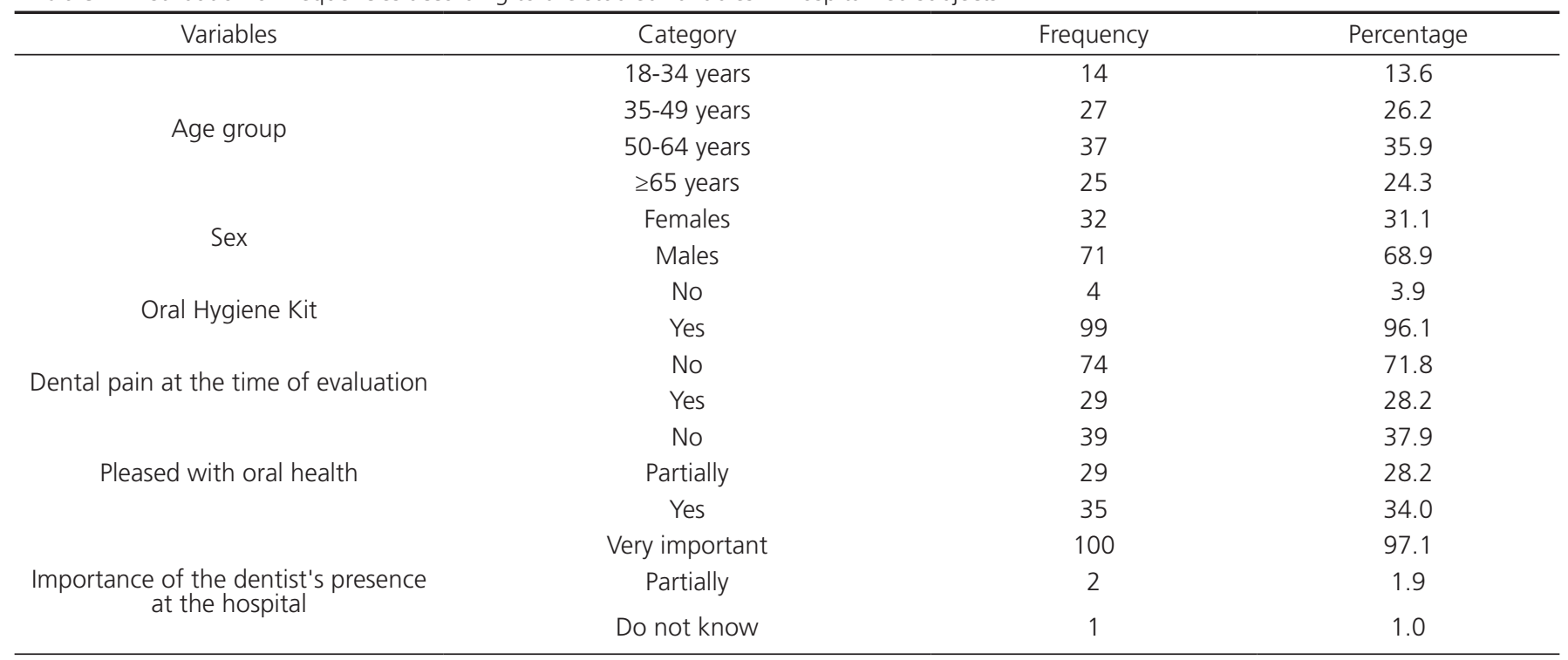

Table 3. Frequency distribution of analyzed variables.

\begin{tabular}{|c|c|c|c|}
\hline Variables & Category & Frequency & Percentage \\
\hline \multirow[t]{2}{*}{ DMFT } & $<$ median (18) & 44 & 42.7 \\
\hline & $\geq$ median & 59 & 57.3 \\
\hline \multirow[t]{3}{*}{ Oral hygiene-visible biofilm } & Excellent & 12 & 11.6 \\
\hline & Satisfactory & 26 & 25.2 \\
\hline & Handicapped & 65 & 63.1 \\
\hline Gingival health & Healthy & 39 & 37.9 \\
\hline
\end{tabular}

Considering the invasive procedures, the evaluation to acute caries lesion, absence of restoration or fractured of the description is shown in Table 4 , in which $68.9 \%$ of restoration, $40.8 \%$ of subjects needed exodontics and subjects showed the need for restorative treatment due $26.2 \%$ reported pain of dental cause.

Table 4. Frequency distribution of the types of invasive procedures required.

\begin{tabular}{ccc}
\hline Dental needs & Frequency & Percentage \\
\hline No invasive or rehab dental treatment need & 18 & 17.5 \\
Restorative treatment indicated & 71 & 68.9 \\
Endodontic treatment & 24 & 23.3 \\
Surgical treatment - Exodontia indicated & 42 & 40.8 \\
Abscess & 8 & 7.8 \\
Pain from dental origin & 27 & 26.2 \\
\hline
\end{tabular}


Table 5 shows an association considering the type of invasive procedure, gingival condition and presence of biofilm. For invasive procedures, it was necessary to apply the test for each category because the same volunteer could show more than one category.

Table 5. Association Considering Age and Type of Invasive Procedure, Gingival Status and Presence of Biofilm.

\begin{tabular}{|c|c|c|c|c|c|c|}
\hline \multirow[t]{3}{*}{ Variables } & \multirow[t]{3}{*}{ Category } & \multicolumn{4}{|c|}{ Age (yers) } & \multirow{3}{*}{ p-value } \\
\hline & & $18-34$ & $35-49$ & $50-64$ & 65 ou mais & \\
\hline & & \multicolumn{4}{|c|}{$N(\%)$} & \\
\hline \multirow[t]{5}{*}{$\begin{array}{c}\text { Dental } \\
\text { Procedures }\end{array}$} & No need & $7(38,9)$ & $2(11.1)$ & 7 (39.9) & $2(11.1)$ & 0.0019 \\
\hline & Restorative & $4(5.6)$ & $24(33.8)$ & $22(31.0)$ & $21(29.6)$ & $<0.0001$ \\
\hline & Exodontia & $2(4.8)$ & $9(21.4)$ & $14(33.3)$ & $17(40.5)$ & 0.0063 \\
\hline & Abscess & $2(25.0)$ & $0(0.0)$ & $3(37.5)$ & $3(37.5)$ & 0.2023 \\
\hline & Dental pain & $6(22.2)$ & $8(29.6)$ & $8(29.6)$ & $5(18.5)$ & 0.3809 \\
\hline \multirow[t]{3}{*}{$\begin{array}{l}\text { Oral hygiene / } \\
\text { Visible biofilm }\end{array}$} & Excellent & $6(50.0)$ & $5(41.7)$ & $0(0.0)$ & $1(8.3)$ & 0.0019 \\
\hline & Satisfactory & $3(11.5)$ & $6(23.1)$ & $12(46.2)$ & $5(19.2)$ & \\
\hline & Handicapped & $5(7.7)$ & $16(24.6)$ & $25(38.5)$ & $19(29.2)$ & \\
\hline
\end{tabular}

\section{DISCUSSION}

Hospitals are composed by multiprofessional groups comprising nurses, doctors, nutritionists, psychologists, biomedicals, pharmacists and physiotherapists; however, most of the time, dental surgeons are not part of the team. Considering this research study, $97.1 \%$ of patients fond it necessary that dental surgeons are present in hospital settings. In a previous study ${ }^{9}$ it was reported that all hospitalized patients considered that it is important to keep their oral health care and, for this, they stated that the presence of dental surgeons in the clinical staff of health care institutions is essential. Dental professionals should join efforts in the search for positive results, focusing on the patient's overall health status ${ }^{23}$. Dentistry should be an integral part of the multiprofessional group, aiming at treating and monitoring hospitalized patients ${ }^{23}$.

Results reported in this study about the importance of dental surgeons in hospitals, the oral care status of hospitalized patients and the dental impairments during the hospitalization period allow the production of epidemiological information considering the oral health status of hospitalized patients, showing that the presence of dental surgeons in hospital settings are important for the achievement of the integral health of patients.

Volunteers evaluated in this study had mean age of 53.1 years of age, with a minimum age of 18 years and a maximum age of 83 years, being $31.1 \%$ female subjects and $68.9 \%$ male subjects. The need for restorative treatment and exodontics were significantly higher in volunteers aged over 34 years of age. The status excellent for oral hygiene was significantly higher in younger volunteers and poor in older volunteers. The literature suggests a correlation between older age and worse oral health status, as well as more severe systemic conditions, due to the increase in the life expectancy of the population ${ }^{3}$.

Considering hospitalized patients, $96.1 \%$ of 
subjects had the oral hygiene kit at the time of admission, however, $63.1 \%$ of subjects presented poor oral hygiene and thick biofilm. There is a deficiency regarding the oral hygiene of hospitalized patients, both by professionals, and by patients and their companions ${ }^{4,5}$. This situation can worsen the systemic condition that may arise from oral status, such as periodontal diseases, caused by the large variety of bacterial species present in the biofilm ${ }^{4,9,20}$. In this study, $62.2 \%$ of patients presented spontaneous our induced gingival bleeding.

Monitoring of the oral health status is done through evaluation and approach of patients in the bedside, observing the neurological and physical limitations caused by their systemic condition? ${ }^{7}$. Most of patients considered dental care to be important in the hospital setting, however, only $34 \%$ of subjects are happy with their oral health status. Such values are lower than those found in a research study published by Gondim et al.22, who reported that $53 \%$ of patients evaluated in the hospital setting said to have good oral health status. However, during hospitalization time, patients and relatives do not care about the oral health status, because the systemic condition has a higher priority, presenting a more severe clinical condition ${ }^{8,22}$.

The experience of caries disease found in the evaluated patients (DMFT) was 17.9 with a minimum of two and a maximum of thirty affected teeth. The literature is homogeneous when it shows an increase in the number of patients requiring dental treatment in a hospital setting ${ }^{1,9}$, in which only $17.5 \%$ of the patients had no need for invasive treatment. The need for restorative treatment that can cause pain and discomfort was found in $68.4 \%$ of hospitalized subjects. At the time of examination, the need for endodontic treatment was observed in $23.3 \%$ of the patients, and $40.8 \%$ of the patients needed dental extractions, which are dental infections that can cause pain, edema and aggravation of the dental status during hospitalization. A fact of concern was that $7.8 \%$ of subjects needed

REFERENCES 1. Jardim EG, Setti JL, Cheade MFM, Mendonça JCG. Atenção odontológica a pacientes hospitalizados: revisão da literatura e proposta de protocolo de higiene oral. Rev Bras Ciênc Saúde. 2013;35(1):31-6.

2. Silva MAM, Pinheiro AKB, Souza AMA, Moreira ACA. Promoção da saúde em ambientes hospitalares. Rev Bras Enferm. 2011;64(3):596-9. doi: 10.1590/S0034-71672011000300027

3. Schmitt BHE, Damos MN, Guzzi SN. Demanda do serviço de odontologia clínica do Hospital de Santa Catarina de Blumenau abscess drainage and $26.2 \%$ of subjects felt dental pain at the time of examination, which demonstrates the importance of the dental surgeon in the hospital setting, working together with the multiprofessional team, providing better assistance when approaching hospitalized patients ${ }^{1-5}$. According to Santana et al. ${ }^{6}$ having the dental surgeon as part of the hospital's multiprofessional team contributes to the prevention of infections, reducing the period of hospitalization and use of medication.

Dental surgeons should be aware of this new working opportunity, learning to work in specific hospital conditions that are different from the routine in the office, working in multiprofessional teams, learning about equipment and medication, interpreting laboratory and imaging tests. These are actions that will make dental surgeons to integrate to the teams, providing integral health care to patients in hospitals ${ }^{23}$.

\section{CONCLUSION}

Health and oral hygiene status of patients were considered poor. Most of patients needed invasive dental treatment, which could cause complications to oral health during hospitalization. Most patients recognized the importance of dental care in the hospital setting.

\section{Collaborators}

COF AMARAL, lead author, design, advisor, literature review and writing of the article. LMR BELON, EA SILVA and A NADAI participated in the data collection, dental and oral clinical tests, dental appointments, and writing the article. MSP AMARAL FILHO, was responsible for monitoring the hospitalized patients's follow-up during the research, checking records, collecting systemic data and writing the article. FG STRAIOTO was responsible for part of the analysis of results and discussion of the results and writing the article.

- SC. Salusvita. 2012;31(3):203-12.

4. Aranega AM, Bassi APF, Panzoni D, Wayana MT, Esteves JC, Junior IRG. Qual a importância da Odontologia Hospitalar? Rev Bras Odontol. 2012;69(1):90-3.

5. Doro GM, Fialho LM, Losekann M, Pfeiff N. Projeto odontologia hospitalar. Rev ABENO. 2005;6(1):49-53.

6. Santana A, Xavier DC, Santos KL, Menezes MV, Piva RM, Werneck RL. Atendimento odontológico em UTI (unidade de terapia intensiva). Rev Herrero. 2011;6(3):19-24. 
7. Matos, FZ, Porto AN, Caporossi LS, Semenoff TADV, Borges AH, Segundo AS. Conhecimento do médico hospitalar referente à higiene e as manifestações bucais de pacientes internados. Pesq Bras Odontoped Clín Integr. 2013;13(3):239-43.

8. Aguiar ASW, Guimarães MV, Morais RMP, Saraiva JLA. Atenção em saúde bucal em nível hospitalar: Relato de experiência de integração ensino/serviço em odontologia. Extensio: Rev Eletr Extensão. 2010;(9):100-10.

9. Lima DC, Saliba NA, Garbin AJl, Fernandes LA, Garbin CAS. A importância da saúde bucal na ótica de pacientes hospitalizados. Ciênc Saúde Colet. 2011;16(supl. 1):1173-80. doi: 10.1590/ S1413-81232011000700049

10. Zution P. Saúde bucal dos pacientes hospitalizados no setor de neurologia do hospital universitário do oeste do Paraná [monografia]. Cascavel: Universidade Estadual do Oeste do Paraná; 2007.

11. Morais TMN, Silva A, Avi ALRO, Souza PHR, Knobel E, Camargo LFA. A importância da atuação odontológica em pacientes internados em unidade de terapia intensiva. Revista Brasileira de Terapia Intensiva 2006; 18(4):412-7. doi: 10.1590/S0103507X2006000400016

12. Santos PSS, Mello WR, Wakim RCS, Paschoal MAG. Uso de solução bucal com sistema enzimático em pacientes totalmente dependentes de cuidados em unidade de terapia intensiva. Rev Bras Ter Intensiva. 2008;20(2):154-8. doi: 10.1590/S0103507X2008000200007

13. Amaral SM, Cortês AQ, Pires FR. Pneumonia nasocomial: importância do microambiente oral. J Bras Pneumol. 2009;35(11):1116-24. doi: 10.1590/S180637132009001100010

14. São Paulo. Secretaria de Saúde. Manual de Odontologia Hospitalar. São Paulo: Grupo Tec. de Odontologia Hospitalar; 2012 [citado 2017 Ago 10]. Disponível em: <http://www. saude.sp.gov.br/ses/perfil/cidadao/areas-tecnicas-da-sessp/ saude-bucal/manual-de-odontologia-hospitalar>

15. Miranda AF, Montenegro FLB. Ação odontológica preventiva em paciente idoso dependente na Unidade de Terapia Intensiva (UTI): relato de caso. Rev Paul Odontol. 2010; 32(1):34-8.

16. Jardim CMOV, Paula RM, Castro I, Baiseredo C, Piau CGBC, Montenegro FLB, et al. Promoção de saúde bucal em paciente idosa internada na Unidade de Terapia Intensiva - relato de caso. Rev Portal Divulg. 2015;(44):44-55.

17. Orlandini GM, Lazzari CM. Conhecimento da equipe de enfermagem sobre higiene oral em pacientes criticamente enfermos. Rev Gaúcha Enferm. 2012; 33(3):34-41. doi:

\section{$10.1590 / S 1983-14472012000300005$}

18. Silveira IR, Maia FOM, Gnatta JR, Lacerda RA. Higiene Bucal: prática relevante na prevenção de pneumonia hospitalar em pacientes em estado crítico. Acta Paul Enferm. 2010; 23(5):697700. doi: 10.1590/S0103-21002010000500018

19. Sousa LLA, Rêgo SAP, Lages VA, Prado RRJ. Estado de saúde bucal de pacientes internados em hospital de rede privada [dissertação]. Teresina: Universidade Federal do Piauí; 2010.

20. Dantas BO, Araújo IM, Araújo HBNR, Araújo EC, Bezerra ACB, Miranda AF. Saúde bucal e cuidados na Unidade de Terapia Intensiva. Odontol Planal Cent. 2015;5(1):28-32.

21. Miranda AF, Araújo IA, Araújo HBN, Edmur Araújo EC, Bezerra $A C B$. Oral health promotion in Intensive Care Unit patients: management and adaptations. Global Adv Research J Med Medical Sci. 2015; 4(11):509-13.

22. Gondim CG, Moura WVBD, Lucena RGRD, Silva BRD, Vasconcelos HM, Aguiar AS WD. Saúde bucal de pacientes internados em hospital de emergência. Arq Odontol. 2012;48(4):270-9.

23. Amaral COF, Marques JA, Bovolato MC, Parizi AGS, Oliveira AD, Straioto, FG. Importância do cirurgião-dentista em Unidade de Terapia Intensiva: avaliação multidisciplinar. Rev Assoc Paul Cirur Dent. 2013;67(2):107-11.

24. Ribeiro AA, Portela M, Souza IP. Relação entre biofilme, atividade de cárie e gengivite em crianças HIV+. Pesqui Odontol Bras. 2002;16(2):144-50. doi: 10.1590/S1517-74912002000200009

25. Lobão DS. Condição de saúde bucal e acompanhamento odontológico de crianças portadoras de leucemia linfocítica aguda [dissertação]. Belo Horizonte: Universidade Federal de Minas Gerais; 2006.

26. Brasil. Câmara dos Deputados. Congresso Nacional. Estabelece a obrigatoriedade da presença de profissionais de odontologia em UTI [Internet]. Brasília, DF; 2013 [citado 2017 Ago 10]. Disponível em: http://www.camara.gov.br 